\title{
Familial Amyotrophic Lateral Sclerosis, 1850-1989: A Statistical Analysis of the World Literature
}

\author{
M.J. Strong, A.J. Hudson and W.G. Alvord
}

\begin{abstract}
We present clinical and pathologic data on four previously unreported familial ALS pedigrees and review and analyze by descriptive and exploratory statistical techniques all published cases of familial ALS (18501989). In contrast to the age-dependent incidence of sporadic ALS, the age of onset of familial ALS is normally distributed about a mean of 45.7 years (std. dev. 11.3 years). Survival curves for the familial ALS data also demonstrate a skewed distribution with a median survival time of 24 months with $74 \%$ surviving at 12 months, $48 \%$ at 24 months and $23 \%$ surviving at 60 months. The patient characteristics of age at onset of disease, sex and focus of disease onset are unrelated variables and age at onset of disease is the only predictor of survival (Cox's proportional hazard model, chi-square 14.74, $p=0.0001$ ). By applying accelerated failure time models with a log-normal baseline distribution, estimated probabilities for survival adjusted by age at onset were calculated. It was found that the older the age at disease onset, the shorter the survival.

RÉSUMÉ: La sclérose latérale amyotrophique familiale, 1850-1989: une analyse statistique de la littérature mondiale. Nous présentons des données cliniques et histopathologiques sur quatre pedigrees de SLA familiale qui n'ont encore jamais été rapportés et nous revoyons et analysons par des techniques statistiques descriptives et exploratrices tous les cas de SLA familiale publiés (1850 - 1989). Contrairement aux cas sporadiques de SLA où l'incidence est dépendante de l'âge, l'âge de début dans la SLA familiale est distribué normalement autour de la moyenne qui est de 45.7 ans (écart type 11.3 ans). Les courbes de survie pour la SLA familiale montrent également une distribution dyssymétrique avec un temps de survie médian de 24 mois, $74 \%$ des patients étant vivants à 12 mois, $48 \%$ à 24 mois et $23 \%$ à 60 mois. Les caractéristiques du patient en ce qui concerne l'âge de début de la maladie, le sexe et le site de début de la maladie sont des variables indépendantes et l'âge au début de la maladie est le seul élément prédictif de la survie (modèle d'analyse de survie de Cox, chi-carré $14.74, p=0.0001$ ). En appliquant des modèles de temps de survie ayant une distribution de base log-normale, nous avons estimé la probabilité de survie ajustée pour l'âge de début. Nous avons trouvé que plus l'âge de début était tardif, plus la survie était courte.
\end{abstract}

Can. J. Neurol. Sci. 1991: 18:45-58

In the century since the seminal descriptions of amyotrophic lateral sclerosis (ALS) by Aran, 1.2 Duchenne ${ }^{3,4}$ and Charcot, 5 ALS has remained an etiological enigma. This is due in part to a clinical presentation, as a rule, of only upper and lower motor neuron involvement despite a varied morphological picture in the different forms of the disease, viz. classical sporadic, familial and Western Pacific ALS. Corresponding to the clinical presentation, the most consistent pathological findings in all forms of ALS are corticospinal and lower motor neuron degeneration. However, in the familial type, there are no clinical correlates to the frequent additional findings of degeneration of the posterior columns, dorsal spinocerebellar tracts and nucleus dorsalis of
Clarke.6.7 Also in Western Pacific ALS the characteristic deposition of neurofibrillary proteins in subcortical regions is usually symptomatically silent.8.9 Thus, ALS is a clinically distinctive disorder of the motor system but there are at least three pathological variants with the same clinical features.

The classical sporadic form of ALS is the most common form of the disease - the hallmark of which is a relentlessly progressive and widespread wasting of skeletal muscle accompanying upper and lower motor neuron degeneration. 10-12. The Western Pacific form of ALS, once endemic to Guam, Western New Guinea and the Kii Peninsula, while clinically similar to the sporadic disease, shows a marked tendency towards familial

From the Laboratory of Central Nervous System Studies, National Institutes of Health, Bethesda, Maryland, USA (MJS); the Department of Clinical Neurological Sciences, University of Western Ontario, London, Ontario, Canada (AJH); and Data Management Services Inc., National Cancer Institute, Frederick Cancer Research Facility, Frederick, Maryland, USA (WGA)

Received May 15, 1990. Accepted in final form September 10, 1990

Reprint requests to: Dr. Michael J. Strong, Department of Clinical Neurological Sciences, University Hospital, 339 Windemere Road, London, Ontario, Canada N6A 5A5 
clustering. Although initially interpreted as an inherited variant of classical sporadic ALS, it is now clear that an environmental insult has played a pivotal role in the genesis of this focus. ${ }^{13-16}$ However, until the early epidemiological investigations of the Guamanian focus of ALS, the possibility of classical ALS having a genetic component was considered remote.

Our current understanding of the inheritance characteristics of familial ALS is based largely on studies conducted within the last 30 years 7.17 .23 which have demonstrated that familial ALS is predominantly inherited as an autosomal dominant trait. Although this is also suggested by a limited number of twin studies, ${ }^{24-26}$ at least one set of monozygotic twins was discordant for the disease. 27 Thus it still remains to be determined if the inherited variant of ALS is causally related to a specific environmental insult in a susceptible population (producing a familial clustering) or due to the transmission from one generation to the next of a specific gene defect.

In order to further delineate the clinical characteristics of familial ALS, we have statistically analyzed the data from all published cases of this variant of ALS (1850-1989) and explored the relationships between survivability and the clinical characteristics of the patients. In conjunction with this, we present data on four previously unreported pedigrees of familial ALS.

\section{Family Histories}

Family CS: Four generations of this family developed ALS. Patient $\mathrm{I}-\mathrm{I}$, a male born in 1869, died in 1912 from a "muscle disorder" of short duration. Patient II-2, the daughter of $1-1$, died at age 50 years following a 12 month illness marked by dysphagia, dysarthria and right arm weakness. Both siblings died of unrelated causes. The only offspring of II-2 died at age 45 years following a 12 month illness characterized initially by dysarthria and dysphagia. This progressed to include palatal paresis, symmetric tongue wasting with fasciculations, absent gag reflex and a brisk jaw jerk. The deep tendon reflexes were normal although the sign of Babinski was present on the left. An electromyogram (EMG) was compatible with a lower motor neuron disorder. An autopsy performed elsewhere confirmed the diagnosis of ALS.

The proband, IV-2, developed right thigh twitching and right leg weakness at age 44 years. During the 9 month course of her illness, the patient developed tongue and diffuse four limb atrophy with fasciculations, symmetric global lower extremity weakness and bilateral signs of Babinski. An EMG showed diffuse four limb denervation with normal conduction velocities. Two brothers, aged 48 and 38 years, are healthy. A son, age 21 years, and three daughters (aged 19,17 and 13 years) are also well.

At autopsy, the anterior spinal nerve roots demonstrated a distinct thinning and greyish discoloration. Histologically, the premotor cortex showed chromatolytic pyramidal neurons with hyaline inclusions. Neurofibrillary tangles were occasionally found throughout the motor and premotor cortex and in the postcentral gyrus. The hippocampus was normal. Chromatolysis and inclusions were seen in the $V^{\text {th }}$ (motor), VIth, VIIth and XIIth nuclei, and nucleus ambiguus. Mild pallor of the corticospinal tracts was present. At all levels of the spinal cord, a marked loss of anterior hom cells with gliosis was present, as were ghost cells, hyaline inclusions, increased lipofuscin pigmentation, eosinophilic globular inclusions and corpora amylacea in the adjacent white matter. Additionally, in the lumbar and sacral regions, neuroaxonal swellings, spheroids, neuronophagia and a more striking gliosis were noted. Throughout the spinal cord a mild pallor of the dorsal spinocerebellar tract was noted, accompanied by a loss of cells in the nucleus dorsalis of Clarke. Sections of the tibialis anterior and deltoid muscles demonstrated small fibre grouping and rare regenerating fibres.

Family $G E$ : Two generations of this family are affected. Patient I-1 died at age 49 years after a disease of 4 to 5 years duration marked by diffuse muscle weakness and twitching. The diagnosis at the time of death was ALS.
The proband, II-1, developed right upper extremity weakness at the age of 46 years and died 37 months later with respiratory failure. During the course of the illness, the patient was found to have progressive muscle wasting of all extremities with fasciculations, pathologically brisk deep tendon reflexes with bilateral Babinski signs, and tongue wasting with fasciculations. The sensory exam remained normal. A muscle biopsy showed neurogenic atrophy. An autopsy was not performed. Two male offspring remain healthy.

Patient II-2 developed diffuse fasciculations at the age of 56 years and died 13 months later with diffuse weakness and fasciculations, hyperreflexia with bilateral Babinski signs and, terminally, dysphagia. An EMG demonstrated diffuse denervation. No autopsy was performed.

Family JT: Three generations of this family have ALS. Patient 1-1, a female, died at the age of 36 years with "creeping paralysis" - the pseudonym applied to this disease by this family. The only known offspring died at the age of 44 years after a 4 year history of "creeping paralysis". Two of his three offspring have ALS.

Patient III-1 developed facial weakness at the age of 62 years and was found to have an atrophic, slow moving tongue, diffuse weakness and upper extremity fasciculation. Preceding her death 4 months later, bilateral Babinski signs were present. An EMG showed widespread denervation with normal conduction velocities. No autopsy was performed.

Patient III-2 developed right hand wasting and "twitching" of the upper extremities at the age of 64 years and died 20 months later. At the only recorded neurological examination, she was found to have a distal upper extremity weakness with asymmetric interossei wasting, diffuse fasciculations and normal reflexes. An autopsy demonstrated a marked loss of neurons of the hypoglossal nucleus with gliosis and ghost neurons, pallor of the lateral corticospinal tracts, and a diffuse loss of anterior horn cells. The remaining anterior horn cells showed globular eosinophilic inclusions, chromatolysis and ghost cells.

The remaining sibling, III-3, developed diffuse muscle weakness and wasting at the age of 59 years. On examination she was found in

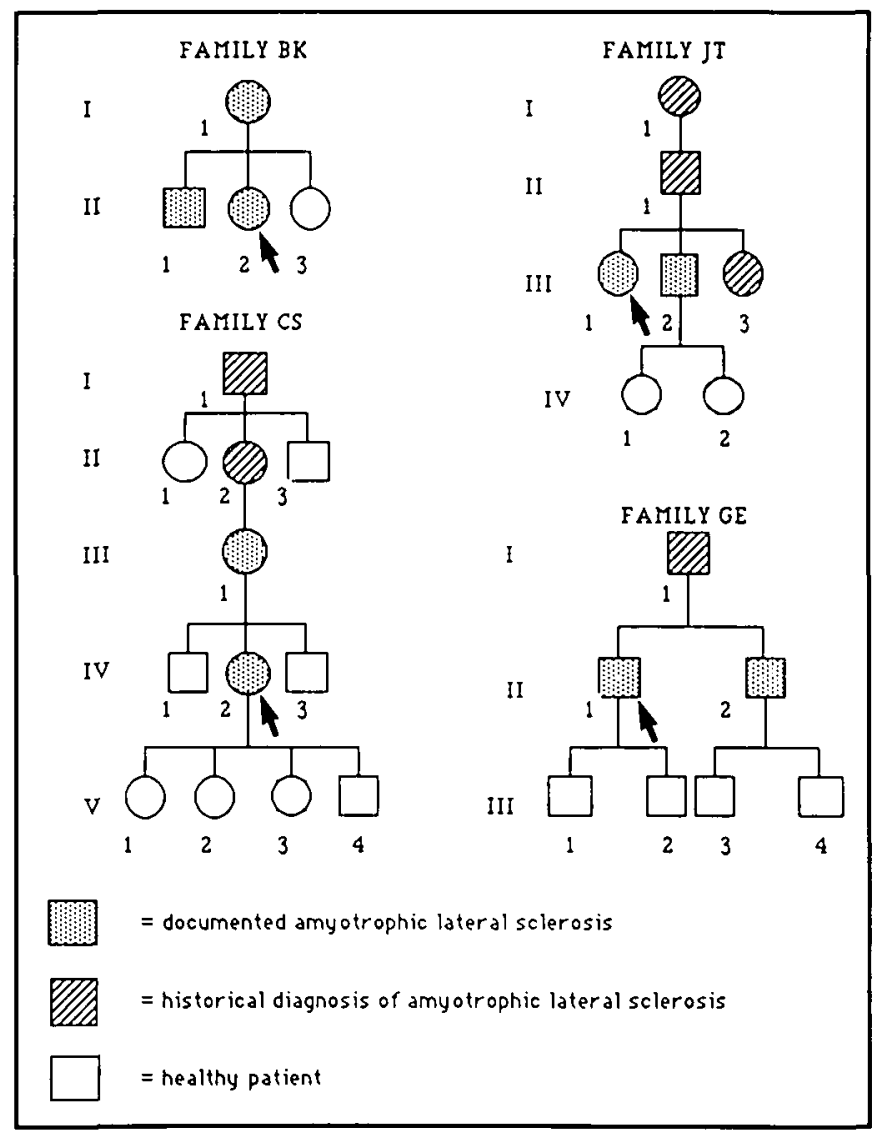

Figure I - Family Trees. The proband is indicated by an arrow: 
addition to have spasticity and bilateral Babinski responses. No bulbar features were noted.

Family $B K$ : An extensive review of this family's pedigree, extending to European ancestry, failed to reveal any individuals afflicted with a neuromuscular disease apart from the following. The mother, I-1, died at age 48 years following an 18 year history of cramps, wasting and muscle twitching. While carried for many years in a provincial muscular dystrophy registry, her ultimate diagnosis was ALS, confirmed at autopsy.

The proband, II-2, first noted a sensation of "worms" in the right calf, associated with frequent cramps and progressive right leg weakness. One year later she was found to have asymmetric plantar flexion weakness, calf wasting with fasciculations, marked wasting of interossei and intrinsic muscles of the feet, pathologically brisk deep tendon reflexes and bilateral Babinski signs. An EMG one year later showed active denervation in both lower extremities. Ten and a half years after the disease onset, the patient remains alive and has developed bulbar dysfunction.

A sibling, $11-1$, initially noted lower extremity twitchings and cramps followed six years later by widespread fasciculations, asymmetric upper extremity and interossei wasting, pathologically brisk deep tendon reflexes and a unilateral Babinski sign. No further progression has been noted.

\section{Literature Evaluation}

\section{Case Ascertainment}

All reports of familial ALS or familial motor neuron disease (MND) in the world literature were collected and subjected to two levels of scrutiny before inclusion in a final analysis. This yielded 100 families with 309 individual cases in the period from 1850 to 1989 . A certain number of reports could be immediately excluded from further analysis in that (i) the cases described did not satisfy the criteria of ALS (7 families), (ii) insufficient history or clinical data was supplied to substantiate a familial categorization ( 11 families), or (iii) the inherited disease included amyotrophy as a component of another neurodegenerative disorder, hereditary or otherwise ( 2 families). The remaining 84 families ( 249 cases), including those of the current authors, underwent a more critical evaluation.

Categorical scores were given to historical, physical, electrophysiological and pathological findings. These values represented a classification index for purposes of statistical analysis and did not imply a specific rank ordering. Historical findings were acceptable if derived from a reliable source (physician or first degree relative giving a complete account) and the clinical findings were derived from an actual recorded assessment. The categorical scores for both history and clinical data are given in Table 1. Electrophysiological assessments (electromyography and nerve conduction studies) were assessed as either (i) not done or done but not compatible with a neurogenic lesion (a score of 0 ), or (ii) done and compatible with the diagnosis of ALS (a score of 1). Compatibility required evidence for denervation in multiple unrelated spinal segments with normal motor nerve conduction velocities ( $>75 \%$ of normal). In a similar fashion the pathology data were assessed a score of 0 or 1 , the latter being those cases with the findings compatible with a histological diagnosis of ALS.

The age of onset was recorded in years (defined as the age at which the patient first noted symptoms) and survival recorded in months (defined as the time of first symptoms to the time of death). Due to the insidious nature of the disease process of ALS, defining the onset of disease is difficult at the best of times. Many case reports did not specify the time of first visit to a physician, or the first appearance of neurological deficits. However, the first appearance of symptoms (e.g. hand weakness, dysphagia, etc.) was uniformly reported. Similarly, while duration is traditionally taken to be the time from clinical disease onset to the time of treatment onset or physician review, and survival taken as the interval thereafter to either death or completion of the treatment protocol, we have utilized time from first clinical symptom to the death as survival. Where possible, the subjective focus of disease onset (the first site of symptoms as reported by the patient) was recorded as either bulbar, lower motor neuron (LMN), or global. The global category was utilized for those cases in which the subjective onset, as recorded, could not be clearly differentiated into the bulbar or LMN categories. Attempts to further differentiate the focus of onset into proximal or distal did not yield additional information.

For inclusion in the analysis, a case required at least one of the following three categorical scores: either (i) a history or clinical exam score of 70; (ii) a clinical score of 30 accompanied by an EMG score of 1 (no clinical evidence of LMN disease, but electrophysiological evidence of such); (iii) a pathology score of 1. All history or clinical scores other than these constituted an exclusion from further analysis. In Table 2 the literature evaluation with scores of acceptable reports are listed.

The pedigree was excluded when application of the inclusion criteria left only one acceptable case and required at minimum one affected first degree relative or affected relatives in two generations. In this way it was intended that a true sporadic ALS case occurring in the setting of other diseases (independently or in combination) involving the motor neuron would be excluded.

Table 1: Categorical scores were applied to the cases of familial amyotrophic lateral sclerosis derived from a literature review (1850-1989). Scores were assigned to the variables of history, clinical observations, electromyography and pathology.

History and Clinical Observations:

\begin{tabular}{lc} 
Observation** & Categorical Score* \\
\hline Bulbar & 10 \\
UMN only & 20 \\
Bulbar plus UMN & 30 \\
LMN only & 40 \\
Bulbar plus LMN & 50 \\
UMN plus LMN & 60 \\
ALS & 70
\end{tabular}

EMG (electromyography):

not done $=0$

done and compatible with ALS $=1$

Pathology:

not done $=0$

done and compatible with ALS $=1$

*Categorical Score: this score does not represent a rank ordering of symptoms and signs, rather it is a classification index for purposes of statistical manipulation.

**UMN = upper motor neuron; LMN = lower motor neuron 


\section{Statistical Methods}

After application of the inclusion criteria, 53 families (149 cases) remained, 144 of which reported survival times. The data were then subjected to a variety of exploratory and confirmatory analytical methods. In addition to survival times, fairly complete data were available on the patient characteristics (concomitant variables) of age at onset of disease, sex, and focus of disease at onset. In general, we felt that multiple methods of analysis tending to the same conclusions would increase confidence in the conclusions.

In the analyses presented here, we began with simple descriptive measures of the concomitant variables age at onset, sex, and focus of disease and thereafter, using log-linear analysis, determined whether any relationships existed among the independent variables. In determining whether certain patient characteristics might serve as prognostic indicators of survival, we then described the survival curve for familial ALS and explored the general question of whether the various subgroups of concomitant variables (e.g. sex) arose from identical survivor functions. Standard nonparametric comparative techniques were used. To determine those patient characteristics that might be related to survival, we fit Cox's (1972) proportional hazards model. ${ }^{60}$ Finally, we compared the results of fitting the proportional hazards model and fully parametric models and developed a simple method for predicting the probability of survival given the patient's age at disease onset.

\section{Standard Descriptive Analysis of Covariables}

A histogram of the age at onset data is shown in Figure 2. The ages were normally distributed about a mean of 45.7 years with a standard deviation of 11.3 years (range $20-72$ years). A test of fit (normal probability plot) showed that the data followed a normal distribution $(\mathrm{p}>0.15)$. In a normal probability plot, variables that are normally distributed will fall along a straight line - deviations from this indicate a distribution other than normal.

A histogram of survival is displayed in Figure 3. In contrast to the normal distributional curve for the age of onset, the distri-

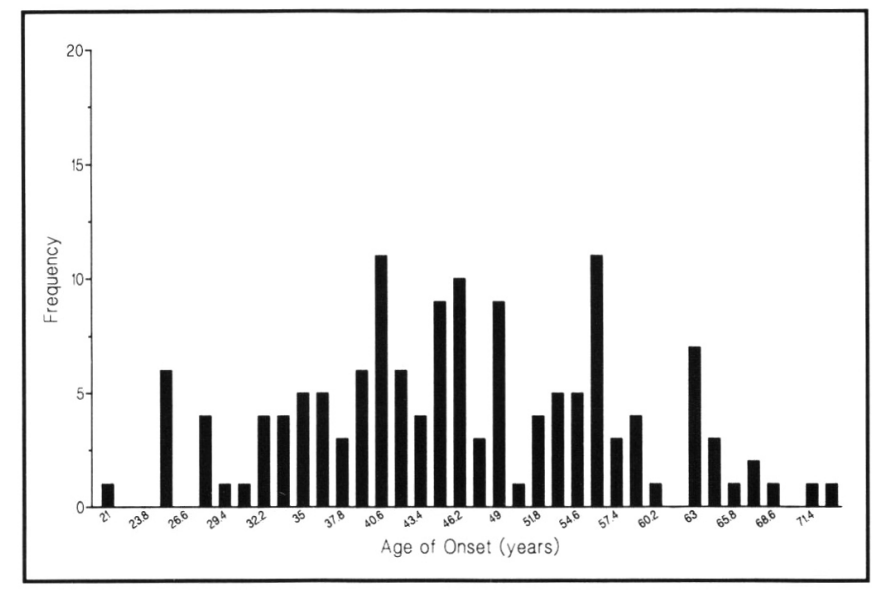

Figure 2 - The age of onset for all cases of familial ALS, illustrated here in a histogram, follow's a normal distribution with a mean age of onset of 45.7 years (std. dev. $11.3 \mathrm{yrs}$ ). bution of survival is decidedly skewed. This visual impression was confirmed by the failure of fit of the data to a normal probability plot.

The male:female ratio was $1.36: 1$. The hypothesis of equal proportions of males and females was tested using the large sample tests statistics, which yielded a value of $1.22(\mathrm{p}=$ 0.2225 ) - nonsignificant. Since test statistics did not indicate any difference in the proportions of males to females, the sex ratio does not differ statistically from $1: 1$.

Prior to investigating possible relationships between the patient characteristics and survival, we performed a series of hierarchical log-linear analyses to examine possible relationships among variables. Information on the focus of disease (global, LMN, bulbar) was available for $126(87.5 \%)$ of the patients in this study. Table 3 shows the cross classification of the 126 patients on these variables. Although age at onset will be treated as a continuous covariate in subsequent analysis, it was dichotomized at 50 years in the present analysis in order to assure a minimum of five observations in each cell and to provide an analysis which would be comparable to traditional studies of sporadic ALS in which age of onset is conventionally dichotomized at 50 years. ${ }^{61-63}$ In the log-linear analyses, the model of complete independence between sex, age and focus is an adequate model for describing the data $\chi^{2}=10.19 ; \mathrm{df}=7, \mathrm{p}$ $=0.1780$ ). Subsequent analyses, which described various relationships between the covariables, were also nonsignificant (details available upon request). Thus, no relationship was shown to exist between sex, age, and focus for this population of ALS patients.

\section{Nonparametric Analysis of Covariates: Relationship to Survival}

Having demonstrated no relationship between these variables, we next addressed the question of the possible impact that age, sex, and focus might have on survival. Summary data and statistics for 144 ALS patients are presented in Table 4. For each variable, the number of patients in each subgroup, the percent of observations that were censored, the median survival (50th percentile) in months and the proportions surviving (along with their standard errors) after 12, 24, and 60 months, respectively,

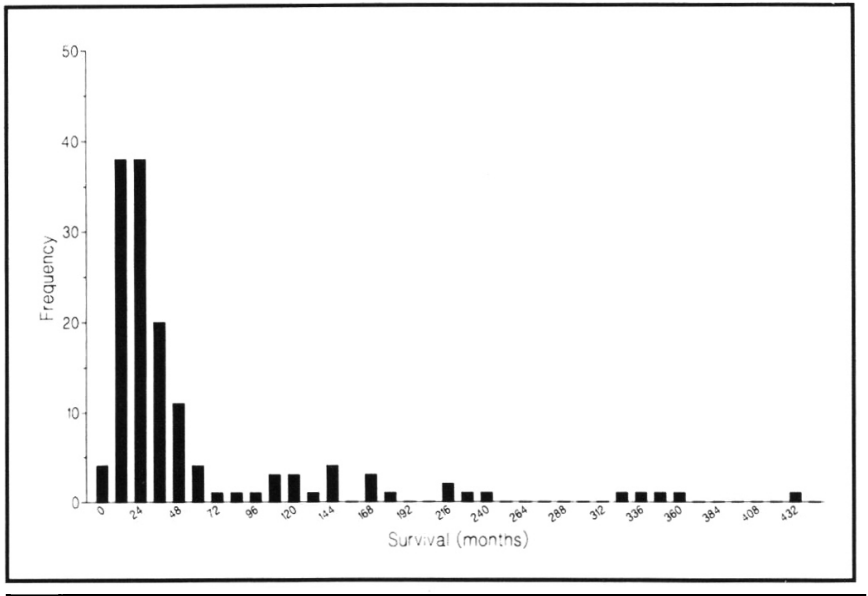

Figure 3 - In contrast to the distribution of age of onset, the survival data for all reported cases of familial ALS is skewed. The histogram also suggests bimodal peaks at approximately 24 months and 144 months. 
Table 2: Familial amyotrophic lateral sclerosis — case reports, 1850-1988

\begin{tabular}{|c|c|c|c|c|c|c|c|c|c|c|}
\hline Author & Case & Sex & $\begin{array}{c}\text { Age of } \\
\text { Onset (yrs) }\end{array}$ & History & $\begin{array}{c}\text { Clinical } \\
\text { Exam }\end{array}$ & EMG & Path & $\begin{array}{l}\text { Survival } \\
\text { (months) }\end{array}$ & $\begin{array}{l}\text { Initial } \\
\text { Focus }\end{array}$ & Comments \\
\hline \multirow[t]{3}{*}{ Aran, $1850^{1,2}$} & 1 & $\mathbf{M}$ & 43 & 0 & 70 & 0 & 0 & 24 & global & \\
\hline & 2 & $F$ & 40 & 70 & 0 & 0 & 0 & 24 & $\mathrm{n} / \mathrm{a}$ & \\
\hline & 3 & $\mathrm{~F}$ & 40 & 70 & 0 & 0 & 0 & 24 & $\mathrm{n} / \mathrm{a}$ & \\
\hline \multirow[t]{3}{*}{ Bernhardt, 188928} & III-4 & $\mathbf{M}$ & 40 & 50 & 70 & 0 & 0 & 20 & distal, UE & \\
\hline & IV-5 & $M$ & 32 & 50 & 70 & 0 & 0 & 20 & proximal, UE & \\
\hline & IV -3 & $\mathbf{M}$ & 36 & 50 & 70 & 0 & 0 & 20 & proximal, UE & \\
\hline \multirow[t]{2}{*}{ Hamilton, $1918^{29}$} & II-I & $\mathrm{F}$ & 55 & 70 & 0 & 0 & 0 & 5 & $\mathrm{n} / \mathrm{a}$ & \\
\hline & IV-12 & M & 44 & 70 & 70 & 0 & 1 & 11 & distal, UE & \\
\hline \multirow[t]{4}{*}{ Schroeder, $1946^{30}$} & I-I & $F$ & 48 & 70 & 70 & 0 & 0 & 42 & distal, UE & \\
\hline & $\mathrm{I}-2$ & $\mathrm{~F}$ & 52 & 70 & 70 & 0 & 0 & 42 & bulbar & \\
\hline & III- 1 & $\mathrm{~F}$ & 56 & 0 & 70 & 0 & 0 & 36 & distal, UE & \\
\hline & III-2 & $\mathrm{F}$ & 63 & 40 & 70 & 0 & 0 & 108 & global & \\
\hline \multirow{2}{*}{$\begin{array}{l}\text { de la Vigne \& Ahmad, } \\
\text { 19523! }\end{array}$} & 1 & $M$ & 45 & 50 & 70 & 0 & 0 & 24 & bulbar & \\
\hline & 2 & $M$ & 68 & 70 & 0 & 0 & 0 & 24 & bulbar & \\
\hline \multirow[t]{2}{*}{ Kurland \& Mulder, $1955^{21}$} & III-23 & $\mathbf{M}$ & 43 & 0 & 70 & 0 & 0 & 13 & global & \\
\hline & I-I & $M$ & 56 & 70 & 0 & 0 & 0 & 24 & $\mathrm{n} / \mathrm{a}$ & \\
\hline \multirow{3}{*}{$\begin{array}{l}\text { "C Family" } \\
\text { (see also Nakano } \\
\text { et al, 1984)32 }\end{array}$} & II-2 & $\mathrm{F}$ & 27 & 70 & 0 & 0 & 0 & 24 & $\mathrm{n} / \mathrm{a}$ & \\
\hline & IV-I & M & 39 & 0 & 70 & 0 & 1 & 7 & $\mathrm{n} / \mathrm{a}$ & \\
\hline & IV-2 & $\mathrm{M}$ & 46 & 0 & 70 & 0 & 1 & 8 & $n / a$ & \\
\hline \multirow[t]{3}{*}{ "F Family" } & II-8 & $\mathrm{M}$ & 33 & 50 & 70 & 0 & 0 & 28 & distal, UE & \\
\hline & III-18 & $\mathrm{F}$ & 25 & 70 & 50 & 0 & 1 & 18 & global & \\
\hline & III-2I & $\mathrm{F}$ & 38 & 0 & 70 & 0 & 0 & 12 & global & \\
\hline \multirow[t]{2}{*}{ "S Family" } & III-5 & M & 55 & 0 & 70 & 1 & 1 & 17 & distal, LE & \\
\hline & III-6 & $\mathrm{M}$ & 33 & 0 & 70 & 0 & 0 & 12 & global & \\
\hline \multirow[t]{3}{*}{ "B Family" } & II-6 & $\mathbf{M}$ & 50 & 40 & 70 & 1 & 0 & 9 & global & \\
\hline & II-4 & $\mathrm{F}$ & 58 & 50 & 70 & 0 & 0 & 8 & global & \\
\hline & $11-3$ & $\mathbf{M}$ & 25 & 40 & 70 & 0 & 0 & 9 & global & \\
\hline \multirow[t]{2}{*}{ Boudin \& Barbizet, $1956^{33}$} & III-1 & $M$ & 42 & 70 & 70 & 1 & 0 & 9 & distal, LE & \\
\hline & II-3 & M & 47 & 70 & 0 & 0 & 0 & 9 & $\mathrm{n} / \mathrm{a}$ & \\
\hline \multirow[t]{2}{*}{ Perry \& Nesky, $1958^{34}$} & 1 & $\mathbf{M}$ & 37 & 50 & 70 & 0 & 0 & 36 & distal, UE & \\
\hline & 2 & $\mathrm{~F}$ & 49 & 50 & 70 & 0 & 0 & 36 & global & \\
\hline \multirow[t]{2}{*}{ Alajouanine \& Nick, 195935} & 2 & $M$ & 66.5 & 70 & 70 & 0 & 0 & 18 & global & \\
\hline & 3 & M & 58 & 70 & 70 & 0 & 0 & 4 & bulbar & \\
\hline \multirow[t]{3}{*}{ Campanella \& Bigi, 195936} & III-8 & $\mathbf{M}$ & 25 & 70 & 0 & 0 & 0 & 360 & global & \\
\hline & III-1I & $\mathbf{M}$ & 40 & 70 & 0 & 0 & 0 & 336 & global & \\
\hline & III-14 & $\mathbf{M}$ & 40 & 70 & 70 & 0 & 0 & 240 & distal, UE & \\
\hline \multirow[t]{3}{*}{ Dierssen Gervas, 195937} & II-4 & M & 54 & 70 & 70 & 0 & 0 & 24 & bulbar & still alive \\
\hline & $\mathrm{I}-2$ & $\mathbf{M}$ & 58 & 70 & 0 & 0 & 0 & 120 & bulbar & \\
\hline & $0-2$ & $\mathbf{M}$ & $\mathrm{n} / \mathrm{a}$ & 70 & 0 & 0 & 0 & 120 & bulbar & \\
\hline \multirow{4}{*}{$\begin{array}{l}\text { Faveret, } 195918 \\
\text { "COD. Famille" } \\
\text { "NER. Famille" }\end{array}$} & III-11 & M & 39 & 50 & 70 & 0 & 0 & 18 & bulbar & still alive \\
\hline & III-1 & M & 31 & 70 & 10 & 0 & 0 & 90 & global & \\
\hline & $11-13$ & $F$ & 56 & 70 & 70 & 0 & 0 & 12 & bulbar & \\
\hline & $11-4$ & $\mathrm{~F}$ & 40 & 70 & 0 & 0 & 0 & 12 & global & \\
\hline \multirow{3}{*}{$\begin{array}{l}\text { Engel et al, } 195917 \\
\text { "A Family" }\end{array}$} & V-56 & $\mathbf{M}$ & 36 & 70 & 70 & 0 & 1 & 12 & distal, UE & \\
\hline & III-9 & $\mathrm{F}$ & 51.5 & 70 & 0 & 0 & 0 & 18 & distal, LE & \\
\hline & III-8 & $\mathbf{M}$ & 35 & 70 & 0 & 0 & 0 & 24 & $\mathrm{n} / \mathrm{a}$ & \\
\hline \multirow{2}{*}{$\begin{array}{l}\text { "B Family" } \\
\text { (see also Hirano } \\
\text { et al, 1967) }\end{array}$} & IV -4 & $\mathrm{~F}$ & 46 & 70 & 70 & 1 & 1 & 20 & global & \\
\hline & IV-2 & $\mathbf{M}$ & 54 & 50 & 50 & 1 & 1 & 9 & global & \\
\hline Aydillo, $1960^{39}$ & II-8 & $\mathbf{M}$ & 20 & 70 & 70 & 0 & 0 & 180 & $n / a$ & still alive \\
\hline & $11-5$ & M & 28 & 70 & 70 & 0 & 0 & 228 & bulbar & \\
\hline & 1.2 & $\mathbf{M}$ & 38 & 70 & 0 & 0 & 0 & 144 & $\mathrm{n} / \mathrm{a}$ & \\
\hline
\end{tabular}


TABLE 2: Familial amyotrophic lateral sclerosis - case reports, 1850-1988 — cont'd.

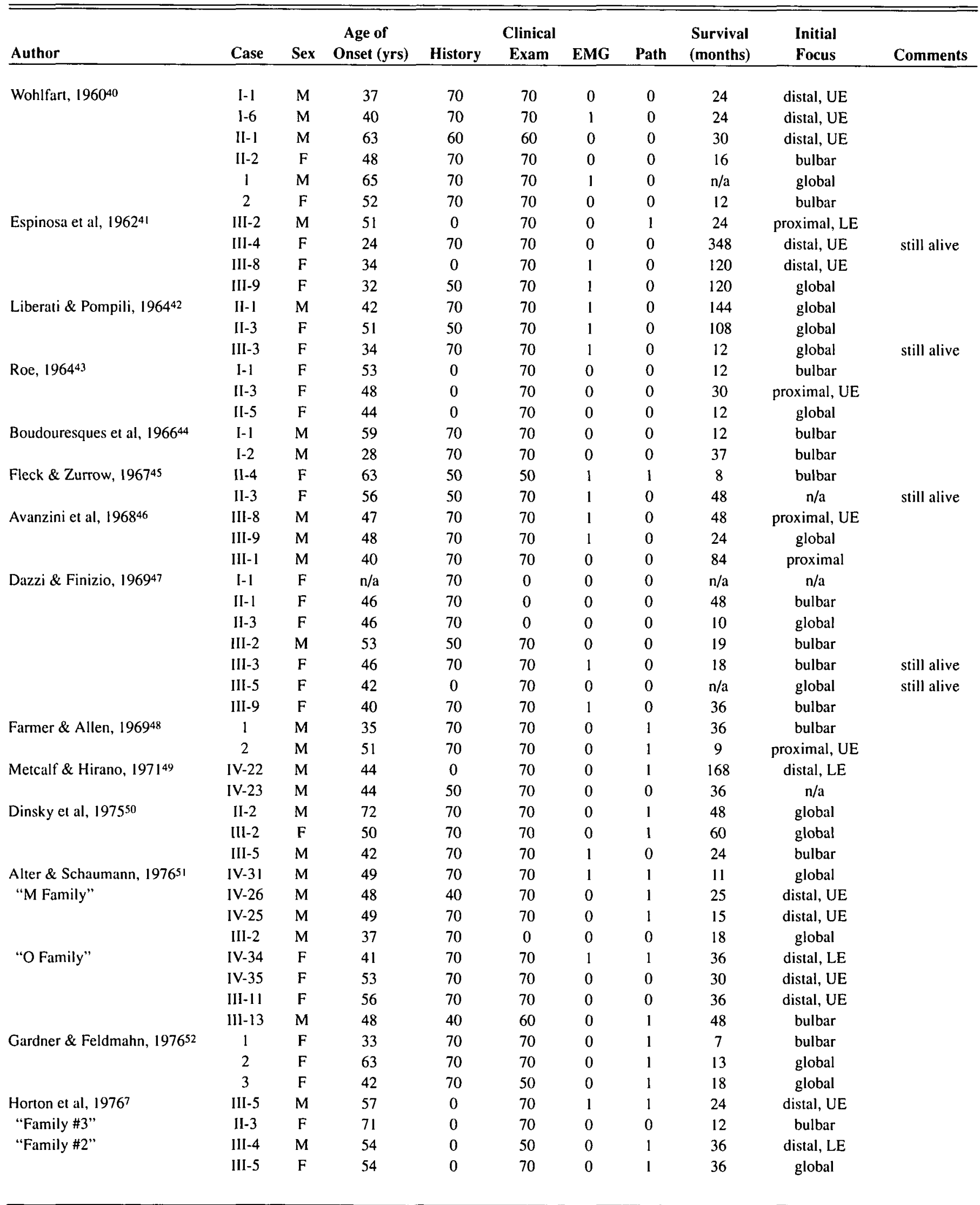


Table 2: Familial amyotrophic lateral sclerosis - case reports, 1850-1988 - cont'd.

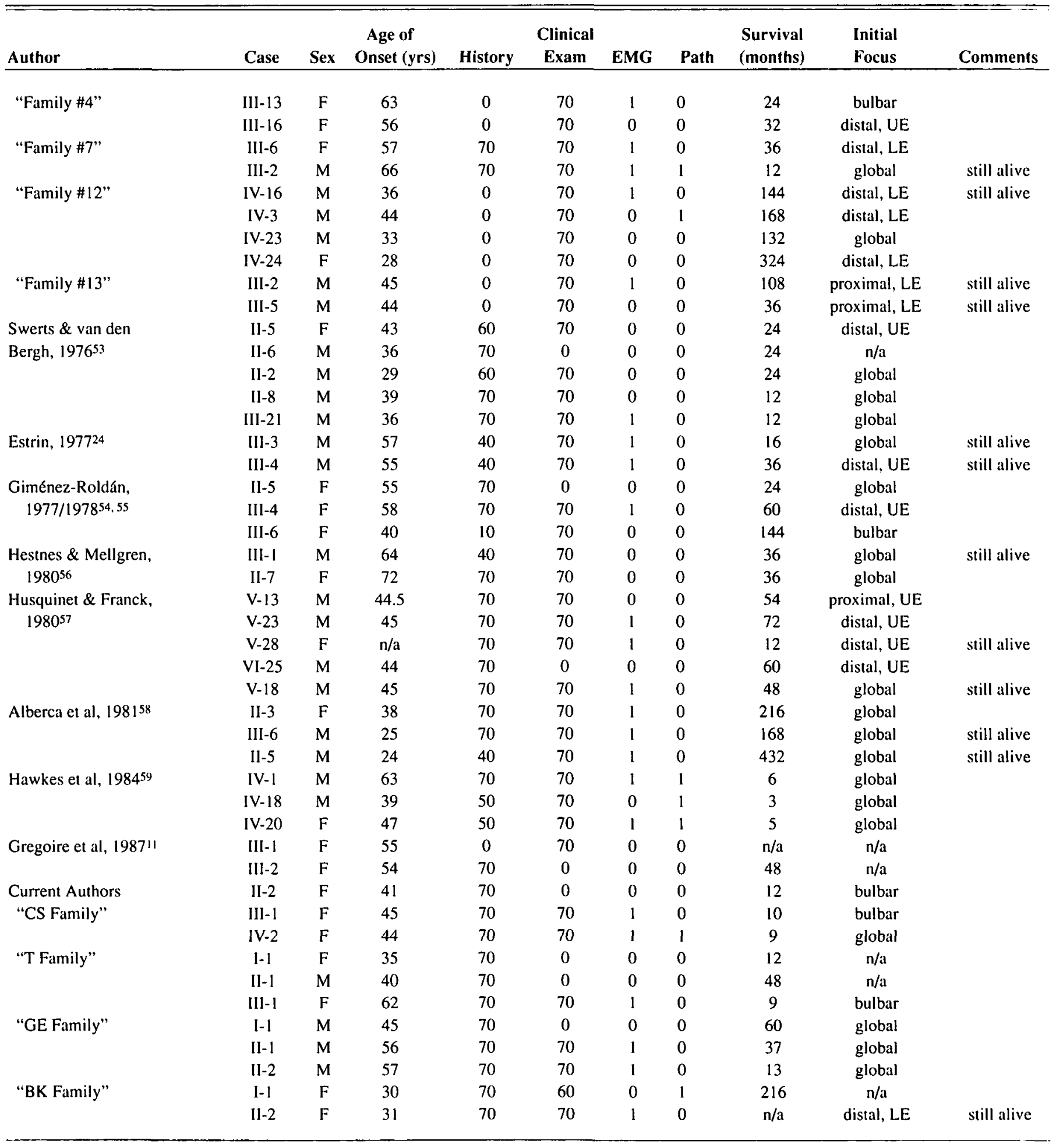

Abbreviations: $\mathrm{UE}=$ upper extremity; $\mathrm{LE}=$ lower extremity; $\mathrm{n} / \mathrm{a}=$ data not available; global = history did not allow for precise differentiation of bulbar vs lower motor neuron onset; path = pathology 
were recorded. Statistics were obtained following the KaplanMeier (product limit) method.64.65

\section{Survivorship Taken Without Respect to Grouping Variable}

For all patients taken collectively, the median survival time was 24 months. Table 4 shows that $74 \%$ of patients survived more than 12 months following the onset of the disease, $48 \%$ survived more than 24 months and $23 \%$ survived more than 60 months. Hence, one-, two- and five-year periods correspond approximately to the first, second, and third quartiles $(25,50$, and 75 th percentiles). Figure 4 shows a Kaplan-Meier survival curve depicting this situation.

\section{Prognostic Variables for Survival}

Age - Table 5 reports the results for ALS patients divided into two age groups, those 50 years or younger and those over 50 years. The proportions surviving in the two groups after 12 and 24 months are similar, falling within 2 standard errors of each other. However, at 60 months only $10 \%$ of the patients in the over 50 group survived, compared to $28 \%$ of the under 50 group. Figure 5 shows the survival curves for each group and suggests a similarity between the two age groups for approximately the first 24 months and an apparently distinct separation by 60 months.

To determine whether this perceived age-dependent difference in survival time was statistically significant, two nonpara-

Table 3: Observations Cross-classified by Sex, Age at Onset (Dichotomized), and Focus of Onset of Disease.

\begin{tabular}{ccccc}
\hline \hline Sex & Age & Bulbar & $\begin{array}{c}\text { Focus of Onset } \\
\text { LMN* }\end{array}$ & Global \\
\hline \multirow{2}{*}{ Male } & $\leq 50$ & 6 & 24 & 21 \\
& $>50$ & 6 & 7 & 10 \\
Female & $\leq 50$ & 8 & 8 & 14 \\
& $>50$ & 8 & 7 & 7 \\
\hline
\end{tabular}

*LMN - lower motor neuron metric statistical tests were performed - the log rank test $^{65 \text {.(pp 16-19) and Gehan's generalized Wilcoxon test. }}{ }^{66}$ The log rank test, which places more weight on longer survival times, is significant at the 0.05 level $\left(\chi^{2}=5.46,1 \mathrm{df}, \mathrm{p}=0.0194\right)$. However, Gehan's generalized Wilcoxon test, which places greater emphasis on early survival times, is not significant $\left(\chi^{2}=\right.$ $1.86,1 \mathrm{df}, \mathrm{p}=0.1721$ ). It appears that the two age groups differ primarily at longer survival times where the risk of death is greater in the over 50 subgroup.

Sex - The median survival time for both sexes was 24 months with no difference in survival rates between the sexes (log rank test: $\chi^{2}=2.18,1 \mathrm{df}, \mathrm{p}=0.1397$; Gehan's generalized Wilcoxon test: $\chi^{2}=1.45,1 \mathrm{df}, \mathrm{p}=0.2272$, both nonsignificant).

Disease Focus - Focus of onset data were available for 126 $(87.5 \%)$ patients. The median survival time for bulbar and global categories was 24 months, while median survival time for the LMN category was 32 months. At 60 months the proportions surviving for the LMN and global groups are equivalent $(0.25$ and 0.26 with s.e.'s of 0.07 ) and the corresponding proportion for the bulbar group $(0.12$, s.e. of 0.07$)$ appears slightly lower but remains within 2 standard errors of the others. The log rank test $\left(\chi^{2}=2.87,2 \mathrm{df}, \mathrm{p}=0.2381\right)$, and the generalized Wilcoxon test $\left(\chi^{2}=4.74,2 \mathrm{df}, p=0.0934\right)$ were both nonsignificant at the 0.05 level, demonstrating no significant differences in survivorship related to focus of disease onset.

\section{Proportional Hazards and Accelerated Failure Time Models}

In the preceding analysis, we examined how the concomitant variables age, sex and disease focus might be related to survival and found that age appears to be the most promising candidate as a prognostic variable. In this section, we apply Cox's proportional hazards model 60 and accelerated failure time models 65 to determine whether concomitant variables acting conjointly help to explain survival time in familial ALS patients (details presented in Appendix I).

Table 5 shows results for three separate fittings of the proportional hazards model to ALS data. In this analysis, age is considered as a continuous covariate ranging from 24 to 72 years (for

TABLE 4: Summary Data for Three Variables Related to Survival (First Symptom to Death) Among 144 Familial ALS Patients.

\begin{tabular}{|c|c|c|c|c|c|}
\hline \multirow{2}{*}{$\begin{array}{l}\text { Variable } \\
\text { \& Levels }\end{array}$} & \multirow{2}{*}{$\begin{array}{c}\text { \# Patients } \\
\text { (\% Censored) }\end{array}$} & \multirow{2}{*}{$\begin{array}{l}\text { Median Survival } \\
\text { (Months) }\end{array}$} & \multicolumn{3}{|c|}{ Proportion Surviving After** } \\
\hline & & & $12 \mathrm{mo}$ & $24 \mathrm{mo}$ & $60 \mathrm{mo}$ \\
\hline All & $144(11.81)$ & 24 & $0.74(0.04)$ & $0.48(0.04)$ & $0.23(0.04)$ \\
\hline \multicolumn{6}{|l|}{ Age } \\
\hline$\leq 50$ & $95(11.57)$ & 24 & $0.75(0.04)$ & $0.50(0.05)$ & $0.28(0.05)$ \\
\hline$>50$ & $49(12.24)$ & 24 & $0.73(0.06)$ & $0.45(0.07)$ & $0.10(0.05)$ \\
\hline \multicolumn{6}{|l|}{ Sex } \\
\hline Male & $83(15.67)$ & 24 & $0.78(0.05)$ & $0.49(0.06)$ & $0.27(0.05)$ \\
\hline Female & $61(6.56)$ & 24 & $0.68(0.06)$ & $0.47(0.06)$ & $0.17(0.05)$ \\
\hline \multicolumn{6}{|l|}{ Focus } \\
\hline Bulbar & $28(10.71)$ & 24 & $0.60(0.09)$ & $0.41(0.10)$ & $0.12(0.07)$ \\
\hline LMN* & $46(10.87)$ & 32 & $0.89(0.05)$ & $0.63(0.07)$ & $0.25(0.07)$ \\
\hline Global & $52(13.46)$ & 24 & $0.69(0.07)$ & $0.42(0.07)$ & $0.26(0.07)$ \\
\hline
\end{tabular}

*LMN - lower motor neuron

** results recorded as: percentage (standard error) 
complete data in Frames $\mathrm{B}$ and $\mathrm{C}$, the minimum age is 20). A single indicator variable distinguishes between men and women and two indicator variables for global and bulbar permit arbitrary location effects for the three focus classes. The asymptotic likelihood ratio chi-square statistics given in the table are calculated by squaring the parameter estimates divided by its standard error. The asymptotic chi-square statistic corresponding to focus differences is calculated as $b^{\top} C^{-1} b$, where $b$ is the vector of maximum likelihood estimates and $C$ is the estimated variancecovariance matrix for $b^{65}$ (p 61$)$. This statistic does not depend on which two focus types are used to define the indicator variables.

From Frame $A$ it is clear that a strong prognostic effect of age is indicated $(p=0.0007)$. Sex and focus of disease do not serve as prognostic indicators (respective $p$ values $>0.05$ ). In Frame B, results are shown for the same analysis on all 144 patients for whom age and sex data were available. Also considered is the possible interaction between age and sex. Age is the only variable that produces a significant prognostic effect $(p=0.0025)$. Frame $C$ shows the results of the stepwise analysis, in which variables are entered in accordance with their prognostic importance. Age is the only variable that is retained $(p=0.0001)$. From these analyses, it is clear that age is the only significant prognostic variable for ALS patients in this study. This finding agrees with our earlier results in which each covariate was studied individually. In the proportional hazards analysis, the age variable is continuous, whereas age was dichotomized in the earlier analysis, resulting in the loss of much information. Hence, the value of age at onset as a prognostic variable appears to be stronger here.

Having identified age as the only important prognostic variable in our application, we investigated four accelerated time failure models, the exponential, Weibull, log-normal, and log-logistic (PROC LIFEREG, SAS, 1985). The log-normal distribution was found to provide the best fit according to several criteria. First, it yielded the highest maximized likelihood of all the competing

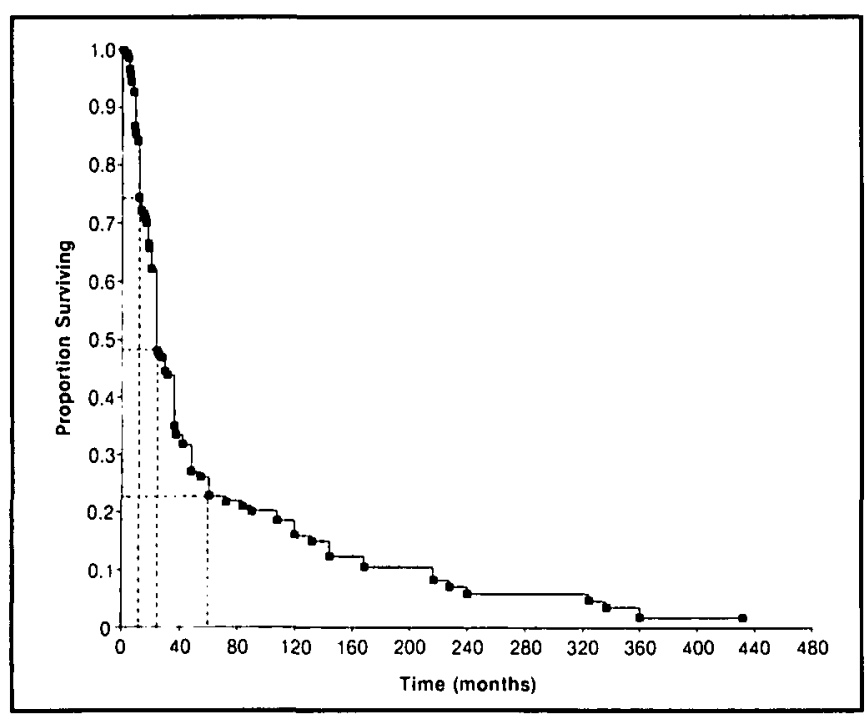

Figure 4 - The Kaplan-Meier survival curve for all familial ALS patients. The percentage surviving at 12, 24 and 60 months are indicated (dashed lines) and correspond approximately to the $25^{\text {th }}$, $50^{\text {th }}$ and $75^{\text {th }}$ percentiles, respectively. models. Second, an analysis of residuals showed that they followed the assumed distributional form, i.e., a normal distribution in $\log _{e} T$ ( $p>0.05$ ). Third, estimated survival probabilities obtained from the log-normal model correlated most highly $(r=0.98)$ with those obtained from the proportional hazards model. Using the log-normal as the baseline distribution, estimated probabilities for survival adjusted by age at onset were calculated. These estimated survival probabilities are displayed in Table 6. For example, the probability of survival at 36 months for a patient who developed ALS at age 30 is $63 \%$, whereas a patient developing the disease at age 60 has a $30 \%$ probability of survival at 36 months.

\section{Discussion}

The first description of ALS by Aran was based largely on the clinical observations of Duchenne. 1.2 Yet the distillation of ALS as a clinicopathological entity is attributed to Charcot. ${ }^{5}$ Similarly, while familial cases of ALS were described by both Aran ${ }^{1,2}$ and Bernhardt, 28 the concept of an inherited form of ALS did not gain acceptance until the later works of Kurland and Mulder, Engel et al, and Faveret. ${ }^{17,18,21}$ The documentation of both familial clustering in the hyperendemic foci of ALS in the Western Pacific ${ }^{67}$ and of several American pedigrees emphasized the distinctive nature of familial ALS.21

The last major comprehensive literature review of familial ALS delineated a primarily autosomal dominant mode of inheritance with an average age of onset of 46.8 years - rarely falling outside of 40 to 60 years. 18.68 The average survival was 30 months with the shortest being 9 months and the longest rarely more than 5 years. The authors made note of previously documented cases of exceptionally long survival but did not recognize these as unique. While only 19 families ( 84 cases) of verifiable ALS could be ascertained when the literature reports were

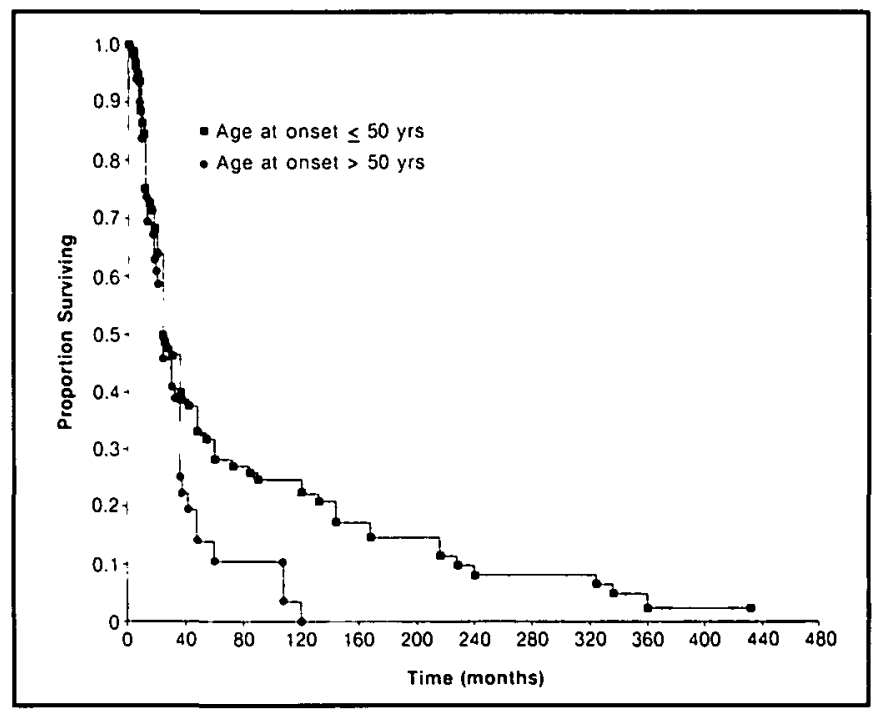

Figure 5 - The Kaplan-Meier survival curve for all familial ALS patients dichotomized at age 50. Survivorship is comparable between the two groups during the initial 24 months. However, by 60 months, distinct differences in the percentage surviving are apparent, a feature most striking after 120 months duration where no patients with disease onsetting at $>50$ years of age are reported. 
categorized according to the validity of the diagnosis, their final analysis contained 29 families (121 cases) - the authors ultimately having included less stringently defined cases for analysis. The majority of these latter families included only one verifiable case of ALS.

\section{Inclusion Criteria}

In this analysis, as in those of recent investigators, we have considered ALS as a clinically distinctive rather than generic disease of the motor neurons. ${ }^{69}$ Therefore, we restricted the cases analyzed to those in which the presence of progressive muscular atrophy (PMA), progressive bulbar palsy (PBP) and pyramidal dysfunction could be unequivocably determined. Thus, although 100 families were found to have been reported as familial ALS or MND, ultimately only 53 pedigrees were determined to be sufficiently well documented to be considered for our analysis. Less stringent inclusion criteria would have embraced such diverse cases as 'long duration' chronic spinal muscular atrophy without bulbar or pyramidal dysfunction, ${ }^{70}$ familial monomelic amyotrophy with hyperreflexia71 or familial monomelic amyotrophy with hyporeflexia ${ }^{72}$ - pedigrees of which have been included in earlier discussions of "familial ALS".

The inability to substantiate a familial diagnosis constituted a major category of exclusion and fell into two broad types. The first type was an inadequate case ascertainment as exemplified by the pedigree reported by Poser in which ALS was documented in the proband but the remaining cases were described only as having had "creeping paralysis" or "progressive muscle atrophy". ${ }^{73}$ Several other families fell into this broad category of exclusion. ${ }^{74-77}$ The second type consisted of those families in which ALS was well documented in the proband yet other fami- ly members suffered from PBP, PMA 78.79 or from such minor changes as hyporeflexia. ${ }^{80}$ Occasional reports were encountered where the proband clearly suffered from ALS, yet the key related case suffered from an unrelated illness mistakenly described as ALS. Examples of such diverse conditions as cervical myelopathy, ${ }^{81}$ progressive supranuclear palsy (ref 82 - case 2),

Table 5: Results of Fits of the Proportional Hazards Model to Familial ALS Data

\begin{tabular}{lcccc} 
Variable & $\begin{array}{c}\text { Parameter } \\
\text { Estimate }\end{array}$ & $\begin{array}{c}\text { Standard } \\
\text { Error }\end{array}$ & $\begin{array}{c}\text { L.R. } \\
\text { Chi-Square }\end{array}$ & $\begin{array}{c}\mathbf{p} \\
\text { Value }\end{array}$ \\
\hline \multicolumn{5}{c}{ Frame A: Focus data $(\mathbf{n}=\mathbf{1 2 6})$} \\
Age & 0.0296 & 0.0087 & 11.63 & $0.0007^{*}$ \\
Sex & 0.1994 & 0.1991 & 1.05 & 0.3057 \\
Focus & & & 1.65 & 0.4382 \\
Global vs LMN & 0.0896 & 0.2199 & & \\
Bulbar vs LMN & 0.3277 & 0.2578 & &
\end{tabular}

Frame B: Age and sex data $(n=144)$

$\begin{array}{lrlll}\text { Age } & 0.0314 & 0.0104 & 9.17 & 0.0025^{*} \\ \text { Sex } & 0.3379 & 0.7079 & 0.23 & 0.6331 \\ \text { Age } \times \text { sex } & -0.0037 & 0.0147 & 0.06 & 0.8031\end{array}$

Frame C: Age data $(n=144)$

$\begin{array}{lllll}\text { Age } & 0.0306 & 0.0080 & 14.74 & 0.0001^{*}\end{array}$

*significant beyond the 0.01 level

Table 6: Estimated Probability of Survival for Familial ALS Patients Based on Age at Onset of Disease.

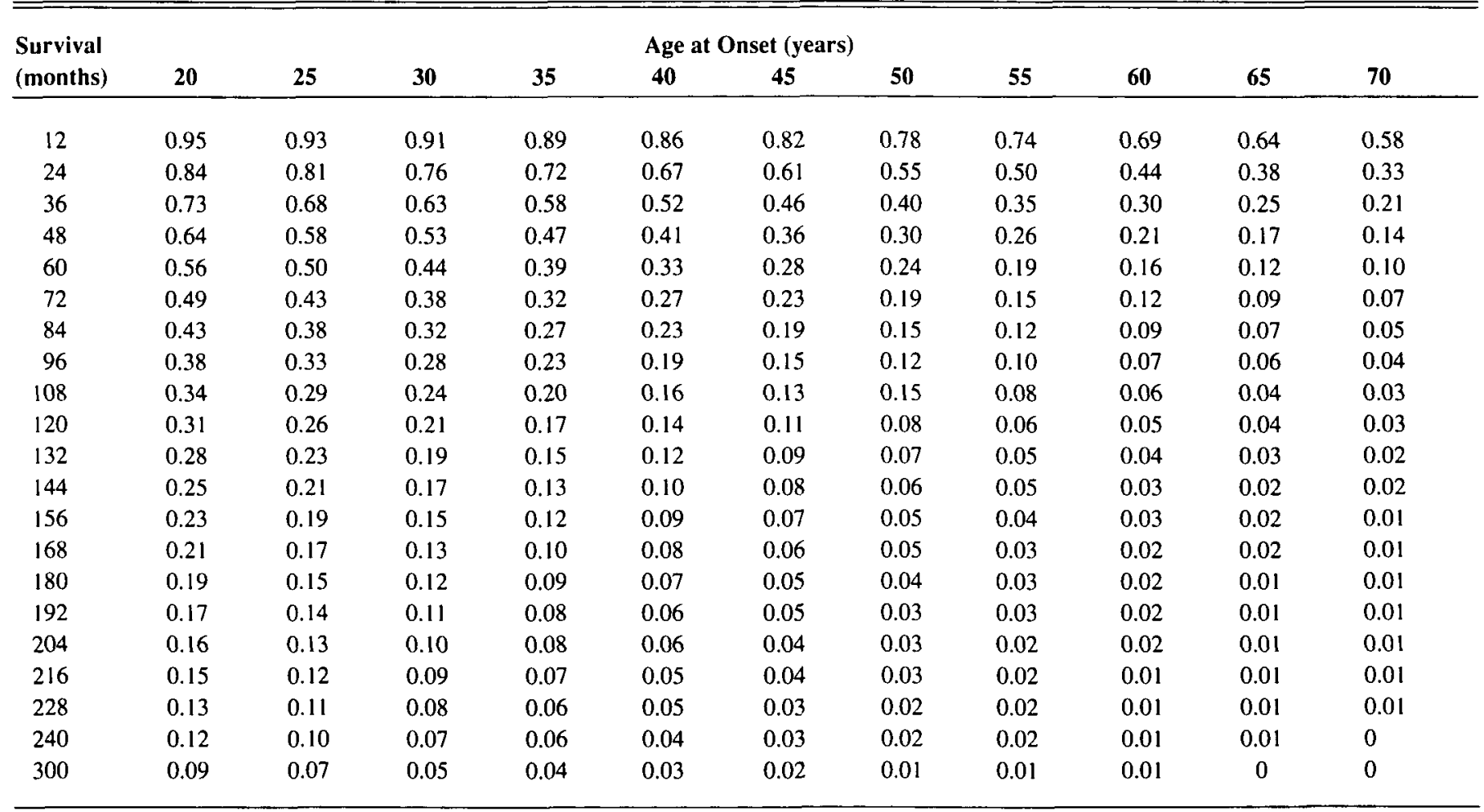


scapulohumeral dystrophy 83 and probable radiation myelopathy (ref 33 - Famille M. Bla., case II-7) were found. In some cases, no diagnosis was recorded. 33,84

Rarely, as typified by the Farr family of Vermont, independent authors reported on successive generations of the same family. Initially described by Osler as a pedigree of PMA, this family was further expanded upon by Brown, and eventually described histologically by Powers. $85-87$ While this latter report confirmed the diagnosis of ALS in a single case (accompanied by changes in the posterior columns and dorsal spinocerebellar tracts), the remainder of the pedigree did not meet the inclusion criteria.

\section{Characteristics of Familial ALS}

After the application of the categorical scores, 149 cases in 53 pedigrees remained in which we could be certain of the diagnosis. Taking this as our data base, several inferences could be drawn about the clinical characteristics of the disease. Firstly, in contrast to the age-related incidence of the sporadic form of ALS that indicates an increasing disease incidence with increasing age, 62.88 we find familial ALS patients, as a group, to be normally distributed about a mean age of onset of 45.7 years. This is virtually identical to the observations of others: 47.7 years, 21 46.8 years, ${ }^{18} 45.1$ years. ${ }^{10}$ The sex ratios (M:F) do not differ significantly from 1:1. The concomitant variables age at onset of disease, sex and disease focus are clearly unrelated variables, and of these, only the age at onset of disease was found to be a predictor of survival. In this regard, it is particularly significant that we have found no correlation between the clinical focus of disease onset and survival. Based on the analysis of the hyperendemic focus of ALS on the Kii Peninsula, one might have anticipated that long duration cases would typically have onset with PMA ${ }^{89}$ - a feature which our data does not demonstrate.

The survival curve for familial ALS is markedly skewed. While the median survival for the population as a whole is 24 months, $23 \%$ of patients are still alive at 60 months. In common with survival data of sporadic ALS data, $26 \%$ of patients who developed ALS at less than age 50 survived to 60 months, whereas only $10 \%$ with onset at greater than age 50 survive at 60 months. 61.62 This analysis, however, contrasts with a recent analysis of familial MND in which the mean duration was demonstrated to be 11 months. ${ }^{90}$ This analysis is not only at odds with this study, but also that of previous authors. 10.18 It is possible that a combination of several diseases of the motor neurons within one analysis may have introduced a bias towards more 'malignant' cases. A rapidly progressive form of familial ALS with death occurring within a year of disease onset has been well documented, (ref 18 - Famille 'NER', ref 21 - 'B family', 29, 33, 59, 91) leading us to have previously considered this a 'malignant' subgroup. ${ }^{92}$ In this current analysis, we were unable to confirm the existence of this as a distinct subgroup. Families expressing a tendency towards a rapidly progressive form of ALS seem to be only a curiosity within the continuum of familial ALS.

Our demonstration of $23 \%$ of patients still surviving at 60 months is compatible with the notion of an exceptionally slowly evolving variant of familial ALS.7.39.49 Horton et al have proposed that these cases might be considered as a distinct subpopulation of familial ALS.7 A similar finding has been suggested for sporadic ALS. In an extensive review of 515 cases of sporadic MND in Japan, Kondo and Hemmi demonstrated the existence of two subpopulations of ALS patients based on disease duration and suggested an improved prognosis in those patients surviving longer than 46 months. ${ }^{93}$ However, in neither of these analyses was the relationship of age at onset to survival explored. As we have demonstrated, age at onset is a highly significant predictor of survival for familial ALS and should be treated as a covariable in the analysis of survival. Thus, it is not clear that the existence of long-term survival patients in the previous studies is not solely related to age of onset. This question is the subject of ongoing analyses.

By demonstrating that age at onset is the only clinical variable which impacts on survival, we were able to calculate survival probabilities based on the knowledge of age at onset (Table 6). We treated the data base as independent case reports to arrive at these survival probabilities, rather than as a collection of pedigrees. The importance of this is highlighted by the report of Chio et al, in which a significant interfamilial but not intrafamilial variability in the age of onset and survival within eight families with motor neuron diseases was documented. ${ }^{94}$ Unfortunately, it is not clear that progressive bulbar palsy was present in all cases, making direct comparisons with our data questionable. Similarly, Williams et al have recently suggested that there may be significant underreporting of cases in familial ALS pedigrees. ${ }^{95}$ Nonetheless, Chio's results do suggest that, in predicting the phenotypic expression of a given case, the antecedent family history must be heavily weighted. Although our retrospective analysis does not lend itself to this type of linkage analysis, there is a tendency towards an uniformity of disease duration within many of the pedigrees. One rarely finds exceptionally short-term survival within families where the predominant expression is a long-term survival. Within the longterm survival families, there is also a striking uniformity of survival. The exceptions to this are the families of Dierssen Gervas; ${ }^{37}$ Espinosa, Okihiro, Mulder and Sayre; ${ }^{41}$ Liberati and Pompi. ${ }^{42}$ Even in these latter families, only single cases are expressed outside the family propensity. We suggest, therefore, that the application of Table 6 in a clinical setting be done in the context of a detailed family history. When the pedigree itself does not demonstrate a significant trend to either extremes of survival, survival estimates taken from Table 6 are likely to be of greater use.

\section{Cases Excluded from the Final Analysis}

A surprising number of case reports in the literature were excluded from our analysis. In reviewing these cases, it was apparent that ALS, PBP and PMA can form, in the adult population, a continuum of disease of the motor neuron within a pedigree and while they may be appropriately considered specific disease entities, they, nevertheless, likely bear a common clinicopathological thread. The earliest documentation of this continuum is the pedigree recorded by Hamilton in which two of four members were documented to have ALS, one had both PMA and pyramidal dysfunction without bulbar involvement and the final member had PMA and PBP without pyramidal disease. ${ }^{29} \mathrm{~A}$ similar pedigree was described by both Montanaro and Lopez ${ }^{96}$ and Thompsen and Alvarez. ${ }^{97}$ This spectrum was confirmed histologically in the "B" Family of Engel, Kurland 
and $\mathrm{K}$ atzo 17 in which case IV-4 clinically and histologically had ALS, case IV-3 PMA but pathological evidence of pyramidal disease, case IV-2 PMA and PBP clinically (with additional pyramidal tract degeneration being found histologically; see ref 6) and III-1 flaccid atrophic weakness alone. In a more recently described family, three of five patients failed to express signs of pyramidal dysfunction and a fourth failed to express bulbar findings clinically or histologically while the proband clearly had ALS. 80 The most extensive collection of these illustrative pedigrees are those recorded by Horton, Eldridge and Brody (see ref 7 - families 1, 6, 8, 10,11, 12 and 14).

The postulate that insufficient time had passed for full disease expression in such cases is refuted by the family of Houff, Calabrese and Taylor. ${ }^{98}$ Here, while the propositus failed to manifest either clinical or histological evidence of pyramidal involvement in spite of a 22 year history, the afflicted mother fully expressed the disease. A similar scenario is described by Aydillo, ${ }^{39}$ in which both ALS and PMA is demonstrated in the same family, all cases being of long duration. Instances of PMA and pyramidal dysfunction in the absence of bulbar disease have also been well documented ( 40 - 'B family', 49). We have found no cases of purely pyramidal dysfunction within these pedigrees - a finding analogous to that of other recent studies. ${ }^{26}$

Discerning whether this continuum, in fact, indicates a single gene defect with variable penetrance, one or more unrelated gene defects drawing on a limited phenotypic pool (giving the appearance of a continuum of diseases) or neither remains to be resolved.

\section{Conclusions}

We have utilized descriptive and exploratory statistical techniques to describe the clinical limits of familial ALS. We find that the age of onset is normally distributed about a mean age of 45.7 years, that the survival data is significantly skewed with a median survival of 24 months and $23 \%$ survival at 60 months. Age at onset was found to be the only predictor of survival, with younger age at onset predicting longer survival. There is no relationship between age at onset, sex or focus of disease at onset. It was also apparent from the literature that a spectrum of motor neuron disorders, encompassing ALS, progressive spinal muscular atrophy and progressive bulbar palsy can occur within the same pedigree, suggesting a common pathogenic mechanism. Studies are in progress to determine if these features serve to predict the neuropathological variant of the disease.

\section{APPENDIX I}

In our study, the proportional hazards model takes the following form

$$
\log _{e}\left(\frac{h_{j}(t)}{h_{0}(t)}\right)=b_{1}\left(x_{1}-\bar{x}_{1}\right)+\ldots+b_{p}\left(x_{p}-\bar{x}_{p}\right)
$$

where $h_{i}(t)$ is the hazard function for the $i^{\text {th }}$ individual at survival time $t, h_{o}(t)$ is the hazard function when all patient characteristics (concomitant variable) are at their average value, the $x$ 's represent the concomitant variables (and their cross-product terms), and $\bar{x}$ 's represent average values of patient characteristics $(64-$ sect $10.2,99,100-\operatorname{sect} 7.5)$. The regression coefficients were calculated with the PHGLM procedure101 — first by forcing all variables into the model and subsequently by using a stepwise procedure so that the first patient characteristic to enter the model was the single most important characteristic in predicting survival, the second variable was the second most important, etc. Generally speaking, the hazard function gives the risk of death per unit time so that variables in the equation that tend to increase the hazard function tend to decrease the time to death.

Cox's model (1972) provides a robust method for determining important prognostic factors. One reason is that it does not require specification of the form of the baseline hazard or survivor functions. However, if the baseline hazard and survivor functions can be specified, then accelerated failure time models may be used $(65-$ sect 2.3 .3$)$.

Accelerated failure models may be described by the general form

$$
\mathrm{Y}=\log _{\mathrm{e}} \mathrm{T}=\underline{x}^{\prime} \underline{\beta}+P \mathrm{~W}
$$

where $Y$ is the natural $\log$ of the survival time, $\underline{x}^{\prime}$ is a vector of covariates, $\underline{B}$ is a vector of coefficients, $P$ is a scaling parameter, and $W$ is assumed to follow a specific error distribution. The effect of the prognostic variable(s) is to scale the baseline distribution of death times.

\section{ACKNOWLEDGEMENTS}

Dr. Strong is a research fellow of the Medical Research Council of Canada. The authors are appreciative of the assistance of Ms. Petra Friedrich in translating the German case reports.

\section{REFERENCES}

1. Aran FA. Recherches sur une maladie non encore décrite du systéme musculaire (atrophie musculaire progressive). Arch Gén de Méd (Paris) 1850a; 24(5): 5-35.

2. Aran FA. Recherches sur une maladie non encore décrite du systéme musculaire (atrophie musculaire progressive) ( $2^{\mathfrak{e}}$ article suite et fin.). Arch Gén de Méd (Paris) 1850b; 24(5): 172-214.

3. Duchenne (De Boulogne) GBA. De l'atrophie musculaire avec transformation graisseuse. De l'électrisation localisée. Ed Baillieree, Paris 1855; 622.

4. Duchenne (De Boulogne) GBA. Paralysie musculaire progressive de la langue, du voile du palais er des lèvres; affection non encore décrite comme espéce morbide distincte. Arch Gen Méd 1860; 16: 283-296, 431-444.

5. Charcot JM, Joffroy A. Deux cas d'atrophi musculaire progressive avec lésions de la substance grise et des faisceaux antérolatéraux de la moelle épinière. Arch Physiol Norm Pathol 1869; 2: 354, $629,744$.

6. Hirano A, Kurland LT, Sayre GP. Familial amyotrophic lateral sclerosis. Arch Neurol 1967; 16: 232-243.

7. Horton WA, Eldridge R, Brody JA. Familial motor neuron disease. Evidence for at least three different types. Neurology 1976; 26: 460-465.

8. Rodgers-Johnson D, Garruto RM, Yanagihara R, et al. Amyotrophic lateral sclerosis and parkinsonism-dementia on Guam. A 30-year evaluation of clinical and neuropathological trends. Neurology 1986; 36: 7-13.

9. Tan N, Kakulas BA, Master CL, et al. Observation on the clinical presentations and the neuropathological findings of ALS in Australia and Guam. In: Chen KM, Yase Y, eds. Amyotrophic Lateral Sclerosis in Asia and Oceania. National Taiwan University: Shyan-Fu Chou, 1984; 31-40.

10. Emery AEH, Holloway S. Familial motor neuron diseases. In: Rowland LP, ed. Human Motor Neuron Diseases. New York: Raven Press, 1982: 139-147.

11. Gregoire N, Serratrice G. Atypical forms of familial amyotro-phic lateral sclerosis. Adv Exp Med Biol 1987; 209: 159-164. 
12. Hudson AJ. Amyotrophic lateral sclerosis and its association with dementia, parkinsonism and other neurological disorders. A review. Brain 1981; 104: 217-247.

13. Garruto RM, Yanagihara R, Gajdusek DC. Disappearance of highincidence amyotrophic lateral sclerosis and parkinsonismdementia on Guam. Neurology 1985; 35: 193-198.

14. Plato CC, Garruto RM, Fox KM, et al. Amyotrophic lateral sclerosis and parkinsonism-dementia on Guam. A 25-year prospective case-control study. Am J Epidemiol 1986; 124(4): 643-656.

15. Reed DM, Brody JA. Amyotrophic lateral sclerosis and parkinsonism-dementia on Guam, 1945-1972. I. Descriptive epidemiology. Am J Epidemiol 1975; 101(4): 287-301.

16. Reed DM, Torres JM, Brody JA. Amyotrophic lateral sclerosis and parkinsonism-dementia on Guam, 1945-1972. II. Familial and genetic studies. Am J Epidemiol 1975; 101(4): 302-310.

17. Engel WK, Kurland LT, Klatzo I. An inherited disease similar to amyotrophic lateral sclerosis with a pattern of posterior column involvement. An intermediate form? Brain 1959; 82: 203-220.

18. Faveret $\mathrm{C}$. La sclérose latérale amyotrophique familiale. Thesis pour le doctorat en medicine. Paris, 1959.

19. Haberlandt WF. Genetic aspects of amyotrophic lateral sclerosis and progressive bulbar paralysis. Acta Genet Med Gemell 1959; 8: $369-373$.

20. Haberlandt WF. Aspects génétiques de la sclérose latérale amyotrophique. World Neurol 1961; 2: 356-365.

21. Kurland LT, Mulder DW. Epidemiological investigations of amyotrophic lateral sclerosis 2. Familial aggregations indicative of dominant inheritance Part II. Neurology 1955; 5: 249-268.

22. Siddique T, Pericak-Vance MA, Brooks BR, et al. Linkage analysis in familial amyotrophic lateral sclerosis. Neurology 1989; 39: 919-925.

23. Tan YD, Dolan P, Brooks BR. Symptom progression in familial amyotrophic lateral sclerosis compared with sporadic ALS: A prospective study. Ann Neurol 1989; 26: 139.

24. Estrin WJ. Amyotrophic lateral sclerosis in dizygotic twins. Neurology 1977; 27: 692-694.

25. Dumon J. Macken J, de Barsy TH. Concordance for amyotrophic lateral sclerosis in a pair of dizygous twins of consanguineous parents. J Med Gen 1971; 8: 113-116.

26. Mulder DW, Kurland LT, Offord KP, et al. Familial adult motor neuron disease. Amyotrophic lateral sclerosis. Neurology 1986; 36: $511-517$.

27. Jokelainen M, Palo J, Lokki J. Monozygous twins discordant for amyotrophic lateral sclerosis. Eur Neurol 1978; 17: 296-299.

28. Bernhardt M. Ueber eine hereditare Form der progressiven Spinalen mit Bulbarparalyse complicirten Muskelatrophie. Virchows Arch f Path Anat Physiol 1889; 115: 197-216.

29. Hamilton AS. Familial progressive muscular atrophy in adults. J Nerv \& Ment Dis 1918; 48: 127-150.

30. Schroeder AH. Formas familiares de esclerosis lateral amiotro-fica. Anales de la Facultad de Medicina de Montevideo 1946; 31 : 723-740.

31. de la Vigne R, Ahmad A. Sclérose latérale amyotrophique héréditaire. Rev Neurol 1952; 87: 361-362.

32. Nakano I, Hirano A, Kurland LT, et al. Familial amyotrophic lateral sclerosis. Neuropathology of two brothers in American " $\mathrm{C}$ " family. Neurol Med 1984; 20(5): 458-472.

33. Boudin $\mathrm{G}$, Barbizet $\mathbf{J}$. Formes familiales de sclérose latérale amyotrophique (étude de deux familles). Rev Neurol 1956; 95: 229. 245.

34. Perry IS, Netsky MG. Familial amyotrophic lateral sclerosis. Report of two cases. NC Med J 1958; 19: 229-234.

35. Alajouanine MM, Nick J. Sur trois cas familiaux de sclérose latérale amyotrophique (forme commune; forme bulbaire à évolution aiguë; forme à type de poliomyélite antérieure chronique) survenue dans la même fratrie. Rev Neurol 1959; 100(5): 490-492.

36. Campanella G, Bigi A. Su di un caso di sclerosi laterale amiotrofica a carattere familiare. G Psychiat Neuropatol 1959; 87: 804-811.

37. Dierssen Gervas G. Un caso familiar de esclerosis lateral amiotrofica. Rev Clin Esp 1959; 73: 210-212.

38. Hirano A, Arumugasamy N, Zimmerman HM. Amyotrophic lateral sclerosis. A comparison of Guam and classical cases. Arch Neurol 1967; 16: 357-363.
39. Aydillo NRL. La esclerosis lateral amiotrofica familiar y hereditaria. Estudio de la familia Araque. Trab del Inst Cajal 1960; 52: 153-167.

40. Wohlfart G, Gamstorp I. Chronic progressive disorders of the lower motor neuron. Res Publ Ass Res Nerv Ment 1960; 38: 659-693.

41. Espinosa RE, Okihiro MM, Mulder DW, et al. Hereditary amyotrophic lateral sclerosis. A clinical and pathological report with comments on classification. Neurology 1962; 12(1): 1-7.

42. Liberati F, Pompili A. Sclerosi laterale amiotrofica familiare (contributo clinico). Riv Neurol 1964; 34: 387-405

43. Roe PF. Familial motor neurone disease. J Neurol Neurosurg Psychiatry 1964; 27: 140-143.

44. Boudouresques J, Khalil R, Vigouroux RA, et al. La sclérose latérale amyotrophique familiale (étude clinique d'une famille). Mars Med 1966; 103(4): 312-316.

45. Fleck H, Zurrow HB. Familial amyotrophic lateral sclerosis. NY State J Med 1967; 67(17): 2368-2373.

46. Avanzini G, Lechi A, Mancia D. La sclerosi laterale amiotrofica famigliare. A proposito di una osservazione clinica. Systema Nervoso 1968; 20: 311-319.

47. Dazzi P, Finizio FS. Sulla sclerosi laterale amiotrofica familiare contributo clinico. G Psychiat Neuropatol 1969; 97: 299-337.

48. Farmer TW, Allen JN. Hereditary proximal amyotrophic lateral sclerosis. Trans Am Neurol Assoc 1969; 94: 140-144.

49. Metcalf CW, Hirano A. Amyotrophic lateral sclerosis. Clinicopathological studies of a family. Arch Neurol 1971; 24: 518-523.

50. Dinsky L, Finlayson MH, Libman I, et al. Familial amyotrophic lateral sclerosis with dementia. A second Canadian family. Clin Genet 1975; 7: 186-191.

51. Alter M, Schaumann B. Hereditary amyotrophic lateral sclerosis. A report of two families. Eur Neurol 1976; 4: 50-65.

52. Gardner JH, Feldmahn A. Hereditary adult motor neuron disease Trans Am Neurol Assos 1966; 91: 239-241.

53. Swerts L, Van Den Bergh R. Sclerose laterale amyotrophique familiale. Etude d'une famille atteinte sur trois générations. J Génét Hum 1976; 24(3): 247-255.

54. Giménez-Roldán S, Esteban A. Prognosis in hereditary amyotrophic lateral sclerosis. Arch Neurol 1977; 34: 706-708.

55. Giménez-Roldán S, Esteban A. Esclerosi lateral amiotrofica familiar. Critica de su clasificacion y analysis de 14 familias de origen espanol. Rev Clin Esp 1978; 148(2): 167-173.

56. Hestnes A, Mellgren SI. Familial amyotrophic lateral sclerosis. Report of a family with predominant upper limb paresis and late onset. Acta Neurol Scand 1980; 61: 192-199.

57. Husquinet $H$, Franck $G$. Hereditary amyotrophic lateral sclerosis transmitted for five generations. Clin Genet 1980; 18: 109-115.

58. Alberca R, Castilla JM, Gil-Peralta A. Hereditary amyotrophic lateral sclerosis. J Neurol Sci 1981; 50: 201-206.

59. Hawkes CH, Cavanagh JB, Mowbray S, et al. Familial motor neurone disease. Report of a family with five post-mortem studies. In: Rose FC, ed. Research Progress in Motor Neurone Disease. London: Pitman Books Limited, 1984: 70-98

60. Cox DR. Regression models and life tables. J Royal Statistical Soc 1972; 34: 187-220.

61. Rosen AD. Amyotrophic lateral sclerosis. Arch Neurol 1978; 35 : 638-642.

62. Hudson AJ, Davenport A, Hader WJ. The incidence of amyotrophic lateral sclerosis in southwestem Ontario, Canada. Neurology 1986; 36: 1524-1528

63. Hudson AJ. Amyotrophic lateral sclerosis: Clinical evidence for differences in pathogenesis and etiology. $\ln$ : Hudson AJ, ed. Amyotrophic Lateral Sclerosis: Concepts in Pathogenesis and Etiology. Toronto: University of Toronto Press, 1990: 108-143.

64. Lee ET. Statistical Methods for Survival Data Analysis. Belmont: Wadsworth Publishers, 1980.

65. Kalbfleisch JD, Prentice RL. The Statistical Analysis of Failure Time Data. New York: Wiley, 1980.

66. Gehan EA. A generalized Wilcoxon test for comparing K samples subject to unequal patterns of censorship. Biometrika 1965; 52 : 203-223.

67. Koemer DR. Amyotrophic lateral sclerosis on Guam. A clinical study and review of the literature. Ann Int Med 1952; 37: 1204-1220. 
68. Bonduelle $\mathrm{M}$, Bouygues $\mathrm{P}$, Faveret $\mathrm{CL}$. La sclérose latérale amyotrophique familiale. Presse Med 1959; 67: 1630-1633.

69. Vassilopoulos D. The genetics of motor neurone disease. Prog Clin Biol Res 1989; 306: 91-104.

70. Amick LD, Nelson JW, Zellweger H. Familial motor neuron disease, non-Chamorro type. Report of kinship. Acta Neurol Scand 1971; 47: 341-349.

71. Paulian D, Cardas $M$. Syndrome de sclérose latérale amyotrophique. Type monoplégique brachial et familial. Bull et Mém Soc Méd de Hop de Paris 1934; 1: 859-861.

72. Robinson GW. The spinal type and family form of progressive muscular atrophy as appearing in adults. J Nerv Ment Dis 1917; 45: 401-409.

73. Poser CM, Johnson M, Bunch LD. Familial amyotrophic lateral sclerosis. Dis Nerv Sys 1965; 26(11): 697-702.

74. Bonduelle M, Bouygues $P$. Observation clinique d'un cas de sclérose latérale amyotrophique familiale. Rev Neurol 1957; 96 : 55-59.

75. Barraquer-Farre L, Barraquer-Bordas L. Contribution a la connaissance de l'etiologie de la sclerose laterale amyotrophique. Acta Neuro Psych Belg 1951; 51:264-281.

76. Rutenik G. Familiare amyotrophische Lateralsklerose. Arch Psychiat Nerv Krankh 1938; 107: 248-264.

77. Sercl M, Kovarik J. On the familial incidence of amyotrophic lateral sclerosis. Acta Neurol Scand 1963; 39: 169-176.

78. Green JB. Familial amyotrophic lateral sclerosis occurring in four generations. Neurology 1960; 10: 960-962.

79. Wolfenden WH, Calvert AF, Hirst E, et al. Familial amyotrophic lateral sclerosis. Proc Aust Assoc Neurol 1973; 9: 51-55.

80. Davidenkof S. Note sur l'hérédité dans la sclérose latérale amyotrophique. Rev Neurol 1932; 1: 948-952.

81. Hasaerts-Van Geertruyden. Sur la sclérose latérale amyotrophique héréditaire (une deuxième souche belge). J Génét Hum 1955; 4: 152-163.

82. Yvonneau M, Vital CL, Belly CL, et al. Syndrome familial de sclérose latérale amyotrophique avec démence. Encéphale 1971; 60: 449-462.

83. Bourrat L, Boulliat G, Trillet M, et at. Sclérose latérale amyotrophique familiale à début pseudo-myopathique. Lyon Med 1963; 210: 1117-1123.

84. Raverdy P, de Vernejoul C. Atteinte motrice périphérique au long cours. Rev Neurol 1975; 131(12): 879-882.

85. Osler W. On heredity in progressive muscular atrophy as illustrated in the Farr family of Vermont. Arch Med 1880; 4: 316-320.
86. Brown MR. 'Wetherbee Ail' The inheritance of progressive muscular atrophy as a dominant trait in two New England families. N Engl J Med 1951; 245(17): 645-647.

87. Powers JM, Horoupian DS, Schaumburg HH. Wetherbee Ail. Documentation of a neurological disease in a Vermont family 90 years later. Can J Neurol Sci 1974; 1(2): 139-140.

88. Juergens SM, Kurland LT, Okazaki H, et al. ALS in Rochester, Minnesota, 1925-1977. Neurology 1980; 30: 463-470.

89. Uebayashi $Y$. Long survival cases of motor neuron disease in the Kii Peninsula and Guam. In: Chen KM, Yase Y, eds. Amyotrophic Lateral Sclerosis in Asia and Oceania. National Taiwan University: Shyan-Fu Chou, 1984: 43-64.

90. Li T-M, Alberman E, Swash M. Comparison of sporadic and familial disease amongst 580 cases of motor neuron disease. J Neurol Neurosurg Psychiatry 1988; 51: 778-784.

91. Igisu H, Ohta M, Yamashita Y, et al. Familial motor neuron disease. Japan J Hum Genet 1974; 19: 108-109.

92. Strong MJ, Hudson AJ. Familial amyotrophic lateral sclerosis (ALS). Evidence for distinct populations of phenotypic expression. Can J Neurol Sci 1987; 14(2): 229.

93. Kondo K, Hemmi I. Clinical statistics in 515 fatal cases of motor neuron disease. Determinants of course. Neuroepidemiology 1984; 3: 129-148

94. Chio A, Brignolio F, Meineri P, et al. Familial ALS. Clinical, genetic and morphological features. Acta Neurol Scand 1987; 75(4): 277-282

95. Williams DB, Floate DA, Leicester J. Familial motor neuron disease: differing penetrance in large pedigrees. J Neurol Sci 1988; 86: $215-230$.

96. Montanaro JC, Lopez JA. Esclerosis lateral amiotrofica a tipo hereditario y familiar. Sem Med (B Aires) 1931; 38: 571-574.

97. Thompson AF, Alvarez FA. Hereditary amyotrophic lateral sclerosis. J Neurol Sci 1968; 8: 101-110.

98. Houff SA, Calabrese VE, Taylor JR. Familial amyotrophic lateral sclerosis. Trans Am Neurol Soc 1976; 101: 254-256.

99. Budzar AU, Gutterman JU, Blumenschein GR, et al. Intensive postoperative chemoimmunotherapy for patients with stage II and stage III breast cancer. Cancer 1978; 41: 1064-1075.

100. Cox DR, Oakes D. Analysis of Survival Data. London: Chapman and Hall, 1984.

101. Harrell FE. The PHGLM procedure in SUGI supplemental library user's guide. SAS (Statistical Analysis System) Institute Inc., Version 5 edition, NC: Carey, 1983. 